\title{
OECDpublishing
}

\section{IDENTIFYING THE FACTORS DRIVING WEST AFRICAN MIGRATION}

\section{WEST AFRICAN PAPERS}

July 2018 No. 17

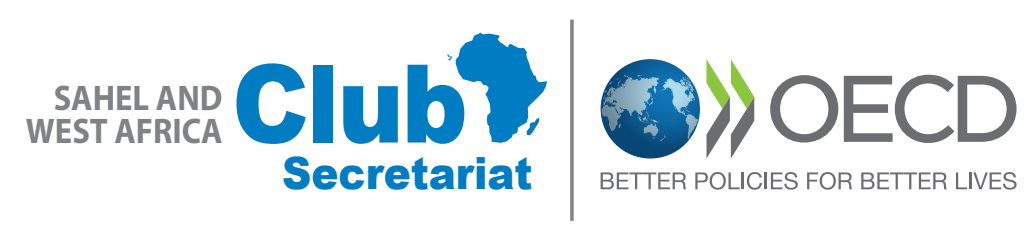





\section{IDENTIFYING THE FACTORS DRIVING WEST AFRICAN MIGRATION}

This paper has been prepared by

MATTHEW KIRWIN

United States Department of State and National Intelligence University 2017-18 Research Fellow

JESSICA ANDERSON

Institute for the Study of International Migration, Georgetown University 


\section{WEST AFRICAN PAPERS}

The West African Papers series explores African socio-economic, political and security dynamics from a regional and multidisciplinary perspective. It seeks to stimulate discussion and gather information to better anticipate the changes that will shape future policies. The series is designed for a wide audience of specialists, development practitioners, decision makers and the informed public. Papers are available in English and/or French, and summaries are available in both languages. Initiated by the Sahel and West Africa Club (SWAC) to highlight and promote West African issues, the work presented is prepared by its Secretariat, Members and partners, other OECD departments, related international organisations, associated experts and researchers.

Please cite this publication as:

Kirwin, M. and J. Anderson (2018), "Identifying the factors driving West African migration", West African Papers, №17, OECD Publishing, Paris.

https://doi.org/10.1787/eb3b2806-en

Authors'contact: mattkirwin@yahoo.com \& jessica.luffman@gmail.com

ISSN 2414-2026

OECD Working Papers should not be reported as representing the official views of the OECD or of its member countries. The opinions expressed and arguments employed are those of the authors.

This document and any map included herein are without prejudice to the status of or sovereignty over any territory, to the delimitation of international frontiers and boundaries and to the name of any territory, city or area.

Working Papers describe preliminary results or research in progress by the author(s) and are published to stimulate discussion on a broad range of issues on which the OECD works. Comments on Working Papers are welcomed, and may be sent to the Sahel and West Africa Club, OECD, 2 rue André-Pascal, 75775 Paris Cedex 16, France.

Authorised for publication by Laurent Bossard, Director, Sahel and West Africa Club Secretariat (SWAC/OECD).

\section{(C) OECD 2018}

You can copy, download or print OECD content for your own use, and you can include excerpts from OECD publications, databases and multimedia products in your own documents, presentations, blogs, websites and teaching materials, provided that suitable acknowledgment of OECD as source and copyright owner is given. All requests for commercial use and translation rights should be submitted to rights@oecd.org. 


\begin{abstract}
Since 2014 over 600000 African migrants have arrived in Italy through the perilous Central Mediterranean route, and nearly 120000 arrived in 2017. This paper is the first examination of migration motivations at the individual level using nationally representative surveys and focus group data collected in West Africa. Respondents in six West African countries cite economic factors as the reason for migrating and those who wish to stay claim family and love of country as the ties that bind. The study then specifically focuses on Nigeria, the country of origin for a quarter of all Africans traveling through the Central Mediterranean route. Half of the Nigerians were interested in leaving their country of origin if given the opportunity, well above the number in neighbouring countries. Evidence from the six-country survey suggests individuals are migrating for economic reasons but statistical analysis of the Nigeria data reveals a different set of push factors behind the desire to migrate. In fact, economic standing has a limited effect on Nigerians' desire to leave their home. Instead, individual perceptions of the strength of Nigeria's democracy are most strongly associated with Nigerians' desire to migrate abroad, in addition to low levels of trust in local security institutions. Urban and more highly educated Nigerians, especially from Lagos, are also more likely to want to migrate abroad. These findings shed new light on domestic policy steps that could address the grievances and concerns of those who seek to migrate.
\end{abstract}

Keywords: migration, migrants, smuggling, Nigeria, West Africa

JEL Classification: J11, O15, O20, R23

\title{
NOTE TO READERS
}

All statements of fact, analysis or opinion are the authors' and do not reflect the official policy or position of the National Intelligence University, the Department of Defense or any of its components, the Department of State, or the U.S. government.

This Note is published as part of the partnership between SWAC/OECD and the Sahel Research Group of the University of Florida. The collaboration aims to:

1. Reinforce ties between research and policies for sustainable development that can help better anticipate changes within the Sahel and West Africa region.

2. Promote West African expertise by reinforcing the links with African researchers and research centres through the Sahel Research Group network.

\section{THE SAHEL AND WEST AFRICA CLUB}

The Sahel and West Africa Club (SWAC) is an independent, international platform. Its Secretariat is hosted at the Organisation for Economic Co-operation and Development (OECD).

SWAC's mission is to promote regional policies that will improve the economic and social well-being of people in the Sahel and West Africa. Its objectives are to:

- Improve the regional governance of food and nutrition security.

- Improve the understanding of ongoing transformations in the region and their policy implications through regional, spatial and forward-looking analyses.

SWAC Members are: Austria, Belgium, Canada, CILSS, the ECOWAS Commission, the European Union, France, Luxembourg, the Netherlands, Switzerland, the UEMOA Commission and the United States.

Germany, Israel, the Network of Farmers' Organisations and Agricultural Producers of West Africa (ROPPA), Norway, Spain, the United Kingdom and the World Bank participate in SWAC meetings as Observers.

SWAC has memorandums of understanding with the NEPAD Agency and the University of Florida (Sahel Research Group).

For more information: www.oecd.org/swac 


\section{TABLE OF CONTENTS}

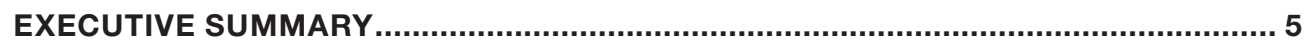

SCHOLARSHIP ON MOTIVATIONS TO MIGRATE.................................................. 6

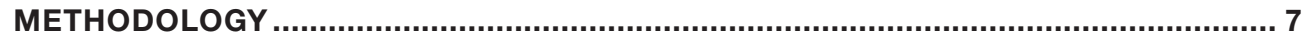

WEST AFRICAN MIGRATION PATTERNS ........................................................... 8

Most West Africans would prefer to stay in their country .................................... 9

The decision to migrate is not a spontaneous one …............................................. 11

Migrants remain undaunted in the face of risks ................................................... 11

Economic opportunities pull West Africans' desire to migrate ................................ 12

WHO WANTS TO MIGRATE IN NIGERIA, AND WHY? .............................................13

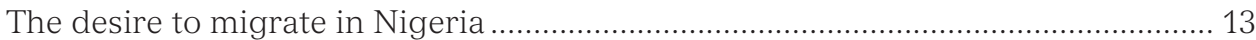

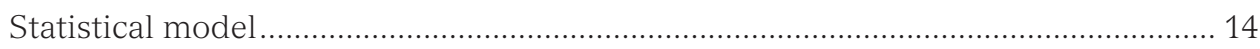

Insecurity not a driver in desire to migrate ...................................................... 16

Economic development does not discourage migration ...................................... 16

Educated urban Nigerians more interested in migrating ...................................... 18

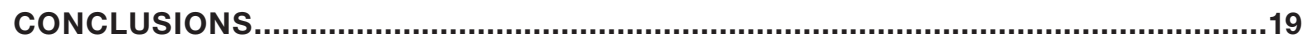

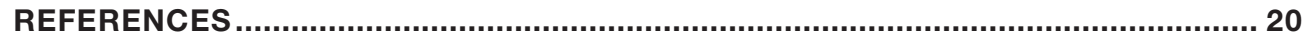




\section{EXECUTIVE SUMMARY}

$\mathrm{T}$ he movement of sub-Saharan Africans through North Africa and on to Europe has garnered intense media attention. Over 600000 African migrants have arrived in Italy through the perilous Central Mediterranean route since 2014, and nearly 120000 arrived in 2017 alone according to the International Organization of Migration (IOM). The route is notoriously dangerous, with risks including making a journey through the Sahara Desert, indefinite detention in bleak conditions in Libya, and capsizing at sea. Though migration numbers dropped significantly in 2017, nearly 20000 migrants were picked up by the Libyan Coast Guard. Migration through Niger and onto Libya has garnered so much attention that European governments have scrambled to slow down the movement.

The implications of migration through the Central Mediterranean route are significant. First, the migration of young and educated workers from a region where human capital is already a scarcity will create a brain drain in an already vulnerable region. Second, the movement of sub-Saharan Africans through North Africa and on to Europe has significant implications for development assistance in West Africa. Third, further understanding the characteristics and motivations behind migration through the Central Mediterranean route is highly relevant for European governments, who have invested significantly in security measures and development assistance to prevent further migration in recent years. Finally, trans-Saharan migration has amounted to a serious humanitarian situation, with people being smuggled across deadly routes, trapped in detention centres, or dying at sea.

This paper fills a crucial gap on the topic of West African migration patterns and the Central Mediterranean route. Several reasons for West African migration are commonly circulated, but they are not based on quantitative survey data. Relying on public opinion and focus group data collected in West Africa, this paper examines what motivates West Africans to leave their countries. It then focuses on Nigeria, the country of origin for a quarter of all Africans traveling through the Central Mediterranean route. The first, and most prominent, contribution of this paper is to provide recent and systematic data on the motivations of West Africans to migrate abroad. For this research agenda, the dataset is unique: it is the first examination of migration motivations at the individual level in a nationwide survey. Second, it examines the effect of a variety of push factors - economic, social and political — on a Nigerian individual's desire to migrate.

\section{Key findings}

- Migrants prepare their journey carefully. In focus groups held with West Africans transiting through Niger on their way to Libya, participants described the years of planning they undertook to make their journey, selling personal possessions, saving money, and relying on their social networks to access resources vital to making the voyage. They gained information to guide their journey through social media tools such as Facebook and WhatsApp both in their country of origin and during their journey.

- Migrants are aware of the perils of the journey. Many of them experienced traumatic events but remained undaunted in their desire to migrate abroad.

- In survey data, the most common reason to stay in one's country of origin was either family or patriotism. A striking number of Nigerians (50\%) were interested in leaving their country of origin if given the opportunity. Ivoiriens (27\%), Senegalese $(27 \%)$ and, to a lesser extent, Burkinabe, Malians, and Nigeriens were also interested in leaving their country if given the opportunity.

- Urban and more highly educated Nigerians are most likely to want to migrate abroad. Religion also plays a role. Muslim Nigerians are much less likely to want to migrate abroad. 
- Economic standing does not have a significant effect on Nigerians' desire to leave their home. Instead, individual perceptions of the strength of Nigeria's democracy are most strongly associated with Nigerians' desire to migrate abroad, followed by low levels of trust in local security.

\section{Recommendations}

- As access to disposable income and other resources increases in the country of origin, more West Africans will be able to migrate. Understanding motivations to migrate among all aspiring migrants will be essential for understanding and addressing future migration patterns.

- Additional research with all aspiring migrants can shed further light on why people want to leave their country. Only a small minority of those who wish to migrate actually do so.

- $\quad$ This paper provides new evidence on domestic policy actions that could address the grievances and concerns of those who seek to migrate. The desire to migrate has the strongest relationship with Nigerians' concerns about the fragility and legitimacy of their state, such as trust in local-level security forces and the functioning of democracy in their country.

This paper is organised as follows. The first section briefly reviews existing literature on motivations for migration and the methodology and data used in this paper. The second section then provides an overview on West African migration and the perceptions of West Africans vis-à-vis the prospect of leaving their country. The paper then presents the results of the Nigeria case study and the effect of a variety of motivating factors on a Nigerians' desire to migrate. The final section describes the implications of these findings and outlines steps for further research.

\section{SCHOLARSHIP ON MOTIVATIONS TO MIGRATE}

D olicymakers tend to assume that economic development will spur a decline in emigration in developing countries. As early as the 1970s, the International Labor Organization (ILO) recommended development assistance as a way to ease migration flows, and donor governments and institutions have followed suit ever since. The European Union, for example, has approved nearly two billion dollars in assistance to curb emigration from sub-Saharan Africa over the past two years (McCormick, 2017).

A long line of migration scholarship comes to a very different conclusion: migration actually rises in lockstep with economic development for a while, as expectations and the ability to migrate increase, and then begins to decline again once countries reach a per capita income of approximately USD 7 000-8 000 (see Sassen 1990; de Haas, 2010; Clemens, 2014; Lucas, 2015). Major theories behind this trend are that economic development reduces barriers to entry for migration, and successful migrants can provide information to potential migrants (Hatton and Williamson, 1994). Others argue that it also creates a growing gap between the haves and have-nots, and relative deprivation prompts people to migrate abroad (Stark, 2006).

Yet, while economic development might create an enabling environment for migration (e.g. reduced barriers to entry), this environment does not necessarily explain why people move. To date, migration scholarship has focused most heavily on the relationship with economic development, but further scholarly work points to a range of other motivations for why people emigrate.

Research on "survival migration" examines non-economic motivations (Betts, 2013). Refugees are necessarily fleeing home because of "a well-founded fear of persecution" or 
civil war, while migrants are categorised as people who voluntarily choose to migrate for the chance of a better life. However, refugees make up less than $10 \%$ of people outside their country of citizenship (UNHCR, 2017). Many others leave their homes because of indiscriminate violence, climate change, or food insecurity. Still others leave because they lack sufficient security or trust in their political system. As Betts (2013: 3) notes, these people "are not fleeing state persecution, though many are fleeing state incompetence."

Many migrants fall into this missing middle category: they experience various kinds of state fragility that do not warrant international recognition as a refugee, but also do not feel like "typical" migration either. Scholars are beginning to more carefully examine the relationship between state fragility and migration. They argue that displacement looks different today than it did in the past, and people often leave their homes because of the risks of a weak state (Betts, 2013). This work is most useful for this paper, and helps to make sense of the Nigeria case findings.

\section{METHODOLOGY}

T his study uses nationwide surveys conducted in Burkina Faso, Côte d'Ivoire, Mali, Niger, Nigeria and Senegal in late 2016 and early 2017. The polls were conducted in local languages by in-country interviewers using face-to-face interviews with adults aged 18 and over (Table 1).

Table 1

Fieldwork and samples size

\begin{tabular}{|c|c|c|c|c|}
\hline Country & States/provinces & Total interviews & Fieldwork dates & $\begin{array}{l}\text { Margin } \\
\text { of error }\end{array}$ \\
\hline Burkina Faso & All 13 & 1907 & 10-30 Jan 2017 & \pm 4 points \\
\hline Côte d'Ivoire & All 31 & 1500 & 14 Nov-31 Dec 2016 & \pm 3 points \\
\hline Mali & $\begin{array}{l}8 \text { of } 9 \text { (excludes Kidal, } \\
\text { parts of Gao and } \\
\text { Timbuktu) }\end{array}$ & 1856 & 21 Nov-22 Dec 2016 & \pm 4 points \\
\hline Niger & $\begin{array}{l}8 \text { (excludes parts of } \\
\text { Agadez, Diffa, and } \\
\text { Tillabéri) }\end{array}$ & 1957 & 8-26 Dec 2016 & \pm 4 points \\
\hline Nigeria & All 37 & 4032 & 21 Nov-31 Dec 2016 & \pm 3 points \\
\hline Senegal & All 14 & 2384 & 2-20 Dec 2016 & \pm 4 points \\
\hline
\end{tabular}

Source: Nationwide surveys, December 2016-January 2017

The questionnaire includes questions pertaining to interest in migration as well as multiple questions focused on social, economic and political perceptions. Extensive demographic questions are also included (see Table 2). It starts with an overview on descriptive statistics of West African perceptions of migration and anecdotes from the focus groups. A model is then developped of Nigerians' desire to migrate abroad if given the opportunity based on survey data collected in Nigeria in December 2016. 
In addition to the survey, research focus groups with aspiring migrants recruited by a local survey firm were held in December 2016 in Niamey and Agadez, Niger, two major transit points on the axis migrants use to reach Libya. Each group consisted of 8 to 10 participants and was moderated by Nigerien research assistants in French. The nationalities of the participants were originally from Benin, Burkina Faso, Cameroon, Côte d'Ivoire, Guinea, Liberia, Mali, Nigeria, Senegal and Togo. Three groups were composed of males while the fourth group consisted of females. The focus groups shed light on the planning and activities of migrants in the middle of their journey to Europe.

\section{WEST AFRICAN MIGRATION PATTERNS}

$\mathrm{T}$ he scope and scale of migration in sub-Saharan Africa is both remarkable and often misunderstood. For instance, despite recognition that West Africans are headed to Europe in growing numbers, there is ten times more migration within West Africa than migration to Europe (Charrière and Frésia, 2017). Meanwhile, in 2017, Africa had more than a billion inhabitants and by 2050 it will have nearly 2.5 billion. According to the Pew Research Center (2018), since 2010, eight of the top ten countries with the fastest growing international migration rates were in sub-Saharan Africa. Migration on and from the continent could reach historically unprecedented levels.

The drivers of migration are changing over time but have undergone limited research. In a recent report by the World Bank, analysts estimate that by 2050 there will 86 million internal migrants in Africa from environmental change alone (World Bank, 2018). Unpredictable push and pull factors for migration are emerging at the same time as the sheer number of aspiring migrants is skyrocketing.

Even though projected rates of migration are rising, migration has also been a vibrant and historically rooted phenomenon in West Africa. The media spotlight has focused on the large number of West African migrants passing through Niger on their way to Libya in hopes of reaching Europe. Yet, migration through Niger into North Africa is a long-standing tradition (Brachet, 2018). Since the end of colonial rule, migration has been considered a common household strategy to diffuse risk (e.g. drought) (Charrière and Frésia, 2008). Though the more recent movement of West Africans has garnered much attention, in previous decades Sahelian people were much more likely to move through the Sahara Desert to North Africa. In fact, according to Grégoire (1999), Nigeriens made up about half of all sub-Saharans who entered Algeria and Libya from Niger in the 1990s.

The trend started to change in the late 1990s when other West Africans started to make up a more significant component of migration to Libya. In the 2000s, President Muammar Gaddafi became an important partner of the European Union (EU) in fighting illegal migration (Raineri, 2018; Brachet, 2018). With his departure from power in 2011 and the ensuing chaos in Libya, many migrants saw an opening in their quest to reach Europe, and the number of sub-Saharan Africans transiting grew significantly (Figure 1).

At the same time, rapid urbanisation over the preceding decades and shocks such as wars in the region (e.g. Côte d'Ivoire, Liberia and Sierra Leone) have increased the volatility of migration rates. Today, the Sahel and the Sahara experience heightened levels of political instability through coups, insurgent groups, rebellions, and large-scale trafficking in arms, people, and other illicit goods (Walther, 2017). These new factors coincide with the advent of smartphones and increasingly accessible Internet, which has provided aspiring migrants with both the encouragement and necessary information to leave their homes. 
Figure 1

Nationality of migrants who arrived in Italy by boat, 2016-17

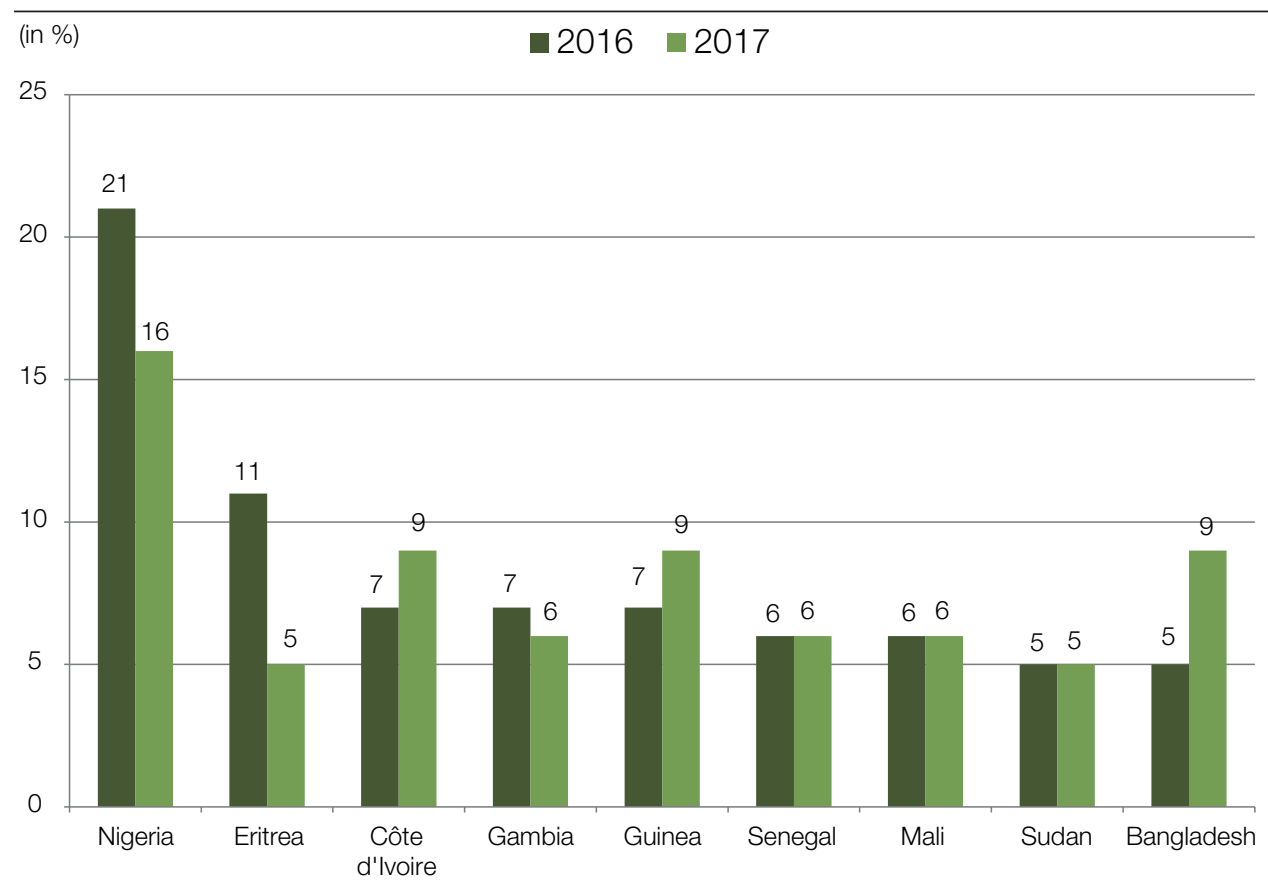

Source: International Organization for Migration (IOM). Arrivals by year 2017: 119 369, 2016: 181436 ,

2015: 153 842, 2014: 170 100. Total between 2014 and 2017: 624747.

\section{Most West Africans would prefer to stay in their country}

Through survey data from Burkina Faso, Côte d'Ivoire, Mali, Niger, Nigeria, and Senegal, the number of people who would migrate if given the means and opportunity varied considerably across these West African countries (Figure 2). Aspiring migrants ranged from a low of 11\% in Niger to a high of 50\% in Nigeria, and about one-in-four in Burkina Faso, Côte d'Ivoire and Senegal. Not all West Africans who want to migrate were aiming for Europe: in general, most African migration is intra-continental. In Burkina Faso, for example, many leave their homeland to find work in neighbouring Côte d'Ivoire. Nigeria has massive diaspora populations in other West African countries while many Nigeriens, particularly those of Hausa origin, seek work in neighbouring Nigeria.

\section{Figure 2}

Would you prefer to live and work in another country or stay in your country?

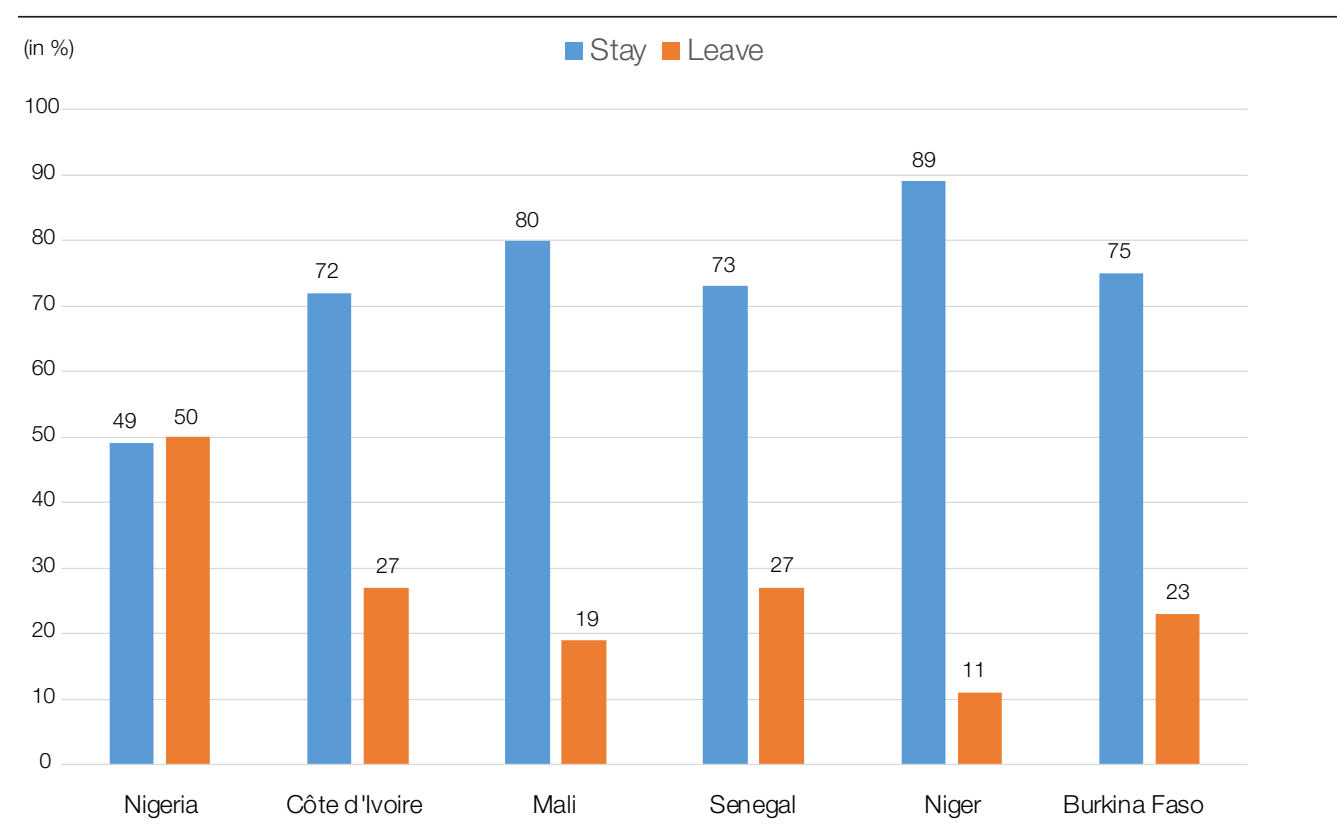

Source: Surveys, December 2016-January 2017. 
Niger, Burkina Faso, and Mali are among the poorest countries in the world according to the United Nations' Human Development Index (187, 185, and 175, respectively out of 188) and yet few people wish to leave their country, even when given the means and opportunity to do so. Nigeria, by contrast, is ranked much higher (152) but far more people consider migration.

Across West Africa, men tend to be more likely to want to leave than women, although this varies based on religion. In Nigeria and Burkina Faso, both countries with significant Christian populations, women are on par with men in their desire to migrate, while in Niger, which is majority Muslim, women are half as open to leaving Niger. In Nigeria, for example, the difference between Muslims and Christians in desire to migrate is stark. According to the survey, about two-thirds (68\%) of Muslims wish to stay in their country, compared with 39\% of Christians. Across all six countries, urban residents are also more likely to want to depart, which is perhaps unsurprising since many urban dwellers have already made at least one move from rural to urban areas. Black and Collyer (2014) argue that urban residents also often desire to migrate but cannot, since they are frequently poor and marginalised but have greater access to information.

While some West Africans are well represented in the clandestine flow of migrants to Europe, others do not figure as prominently. According to the United Nations High Commissioner for Refugees (UNHCR), Burkinabe and Nigeriens are not arriving on the shores of Italy in large numbers. In the surveys, Burkinabe cited love of country (43\%) and family (30\%) as the top reasons they are staying home (Figure 3). Nigeriens also cited those same reasons (38\% and 34\%, respectively). Very few in any country indicated they were staying because the trip is too dangerous. Yet media reports on enslaved West Africans in Libya came out after these surveys were conducted and these stories may now be serving as a deterrent.

\section{Figure 3}

Why would you prefer to stay in your home country?

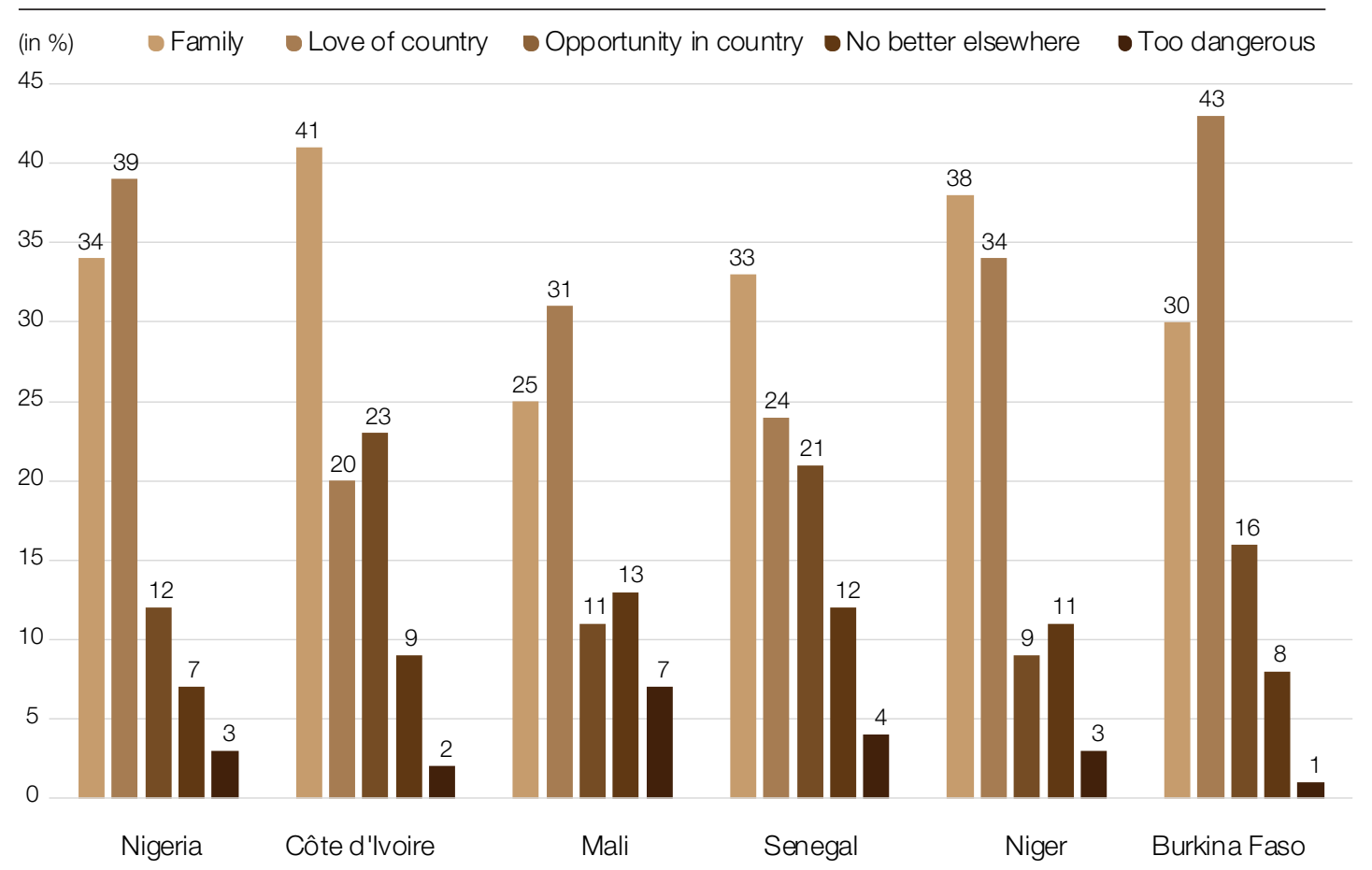

Source: Nationwide surveys, December 2016-January 2017.

Note: The graph shows the percentage of those who say they would stay in home country for the reasons listed. 


\section{The decision to migrate is not a spontaneous one}

While survey data is critical for gaining insights about all aspiring migrants, focus group discussions are equally essential for shedding light on the planning and activities of migrants in the middle of their journey to Europe.

For those aiming to reach Europe via North Africa, the decision to migrate is not a spontaneous one. According to focus group participants, many plan to migrate for a number of years with some reported to have been planning since 2010. In order to finance their journey, many described fundraising among family, selling their possessions, and finding ways to work along their journey. One Guinean man who had worked as a tailor recounted his circuitous journey:

"I sold my sewing machine to get money for the road, I went to work for three months in Côte d'Ivoire. I did not have much success there and a friend told me that Ghana is better. I took my money to go to Ghana, made some more money there, and then made stops to work in Bamako and Burkina Faso before coming to Niamey."

Some participants left their country with as much as 700000 CFA francs (approximately USD 1300), while others left empty-handed and aimed to raise money along their journey. Women in focus groups also mentioned that acquaintances, most frequently people from their country of origin who were now based in Niger, typically sent them money to travel to Niger. A key difference between aspiring migrants and successful migrants is access to resources, such as the money, social networks, and transportation options needed to complete their journey (Carling, 2002).

Many participants had tried legal, formal methods to migrate but had been turned away. Some focus group participants said they had tried to gain legal visas to Europe, but after being denied, they felt that taking the "back way" was the best option (IRIN, 2015). One Ivoirien focus group participant stated that he had travelled to Accra, Ghana on five different occasions in search of a visa to the Netherlands without success.

The journey to Europe is a multi-stage process. In the focus groups, many described how they divided it into segments, often staying in some countries along the way for months or even years to work and raise money. A Togolese woman who participated in a focus group discussion in Agadez said that she had first left Togo in 2011 for Mali and then moved to Niger in 2013. Other women from Cameroon and Nigeria had only been in Niger for several months and planned to move onward. All participants described that they were aiming for Europe via Libya. Still, the structure of the focus group discussion might have steered participants to describe their ideal destination, which may have introduced a minor bias in the results. Migrants explained that they gained information on how to travel through West Africa through Facebook and WhatsApp. Then, once in Niger, they predominantly rely on phone calls. As they move along the journey, they meet other people making the same trek and acquire information along the way.

\section{Migrants remain undaunted in the face of risks}

Thousands of migrants on their way to Italy from North Africa are declared dead or missing at sea each year, according to the International Organization for Migration (IOM). These deaths are likely dramatically underreported due to the clandestine nature of human smuggling. The figure also does not account for what is likely a large number of migrants abandoned in the desert or who die in detention centres and other challenging conditions in Libya.

According to late 2016 surveys in Côte d'Ivoire, Mali, Nigeria and Senegal, large majorities in all four countries were aware of trans-Saharan and trans-Mediterranean migration to Europe. In follow-on focus groups held with migrants in Nigerien transit towns around the same time, most participants stated that they had heard about the risks of the voyage, too. 
Participants were well aware of the risks of their journey, but also knew of people who had succeeded. Many had endured risks already, encountering dead bodies along their journey and walking for long distances. One of the Guinean migrants recounted how some of his fellow travellers had been "left in the desert" and he had no idea if they had survived. A fellow Guinean shared his experience of travel in the desert:

"In the truck in which we came, we were tight as a box of sardines, headed for certain death. We were dropped in the desert, where a man comes to take the migrants to the next destination. If you do not have money, he does not take you and you must walk. Those who were tired no longer had the courage to continue on foot."

One Guinean male recounted that he had already been left in the desert during a previous attempt when his smuggler stole his money. "Others have died, but I will survive" and "I have no fears" were common refrains from the focus group participants. One young man from Senegal stated, "If God says I'm going to die in the desert or in the sea, nothing can change that." Many in the focus groups were so determined to make it to Europe that they did not tell their family of their plans until they had already left their country for fear that their family would attempt to dissuade them.

\section{Economic opportunities pull West Africans' desire to migrate}

According to the data, West Africans who would migrate if given the means and opportunity were far more likely to cite economic benefits as their primary motivation (better jobs and pay, and the opportunity to send money home) than to mention gaining personal freedoms, furthering their education, or escaping insecurity (Figure 4). Focus groups held with West Africans headed to Europe via Libya confirmed the survey results that migrants are motivated primarily by the quest for economic opportunities. As one Ivoirien stated, "I can't just continue to sit in my parents' house with no money or options." In a focus group held in Agadez one woman of Togolese origin stated she left her country "because there is no money there."

Figure 4

What is the main reason you would migrate to another country?

(in \%) $\quad$ Jobs/better pay $\quad$ Send money home $\quad$ Insecurity $\quad$ Education $\quad$ Personal freedom

60

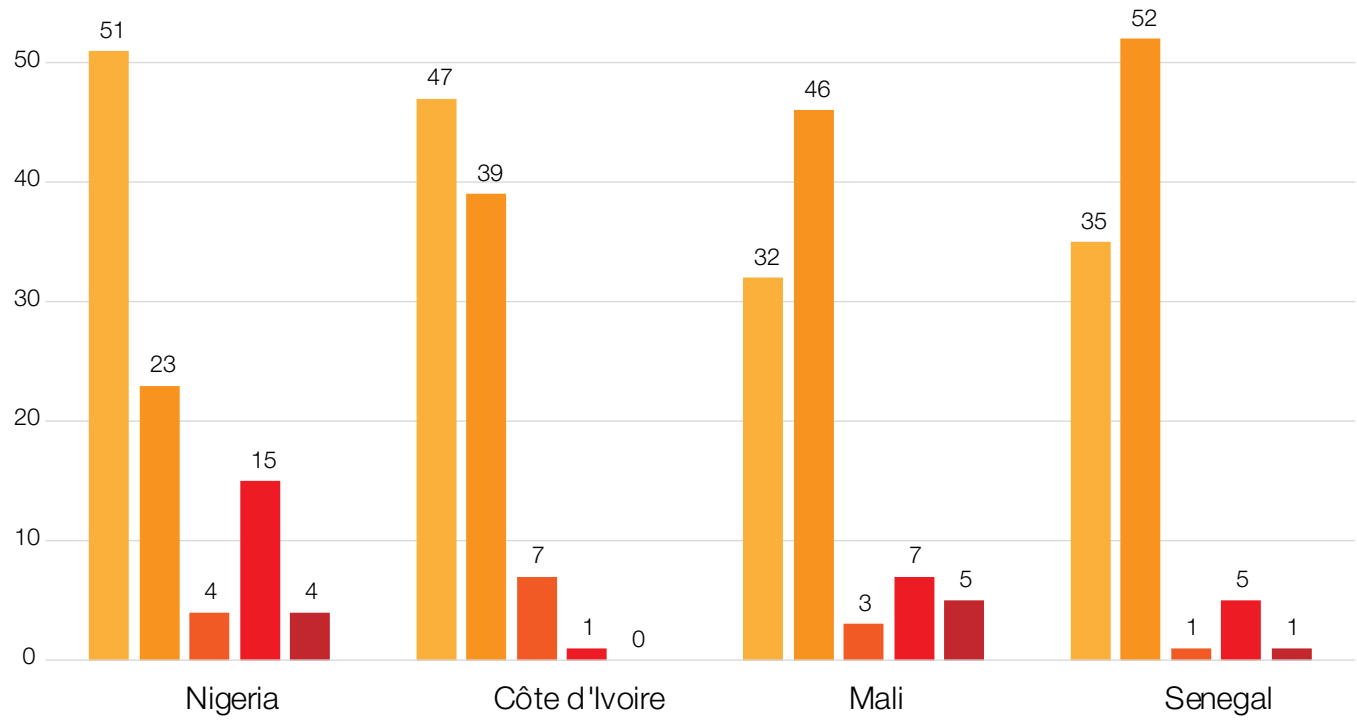

Source: Nationwide surveys, December 2016-January 2017.

Note: The graph shows the percentage of those who say they would migrate if given the means and opportunity. 
A man originally from Guinea made a similar statement, "In Guinea, there are no opportunities, unless you have connections." The reference to "connections" could be an allusion to benign relationships and networks or as pernicious as connections conceived through a bribe. Many see the odds stacked against them in an unfair system in which prospects for upward mobility are constrained by corruption. One Senegalese migrant suggested that staying in Senegal was a no-win situation, saying, "we want to go where we can win." A Beninois migrant stated:

"If we look at the best-educated children, it is the children of the poor. But they never get hired. The children of the rich do the worst in school. A poor person can have all the diplomas in the world but it is the children of the rich rolling in the big cars."

Unsurprisingly, the younger and better educated tended to be much more interested than others in the prospect of migrating, which is further contributing to brain drain in the region (IMF, 2016). In December 2016, during focus groups with migrants in transit through Niamey and Agadez, many of the participants stated they had high school or more advanced diplomas and reported that their degrees did little to advance their careers at home. In fact, a higher level of education, paired with limited employment prospects, appeared to be a motivating factor for migration. As one young man from Côte d'Ivoire noted in the focus groups: "When you finish your studies, you earn your diploma, but you can do nothing with it."

\section{WHO WANTS TO MIGRATE IN NIGERIA, AND WHY?}

The previous section suggested several anecdotal motivations for migration, based on focus group discussions with migrants en route to another country. It also presented survey data examining a set of pull factors for migration, in which better jobs and pay was the most common motivation. And yet, it is possible this finding over-determines the role of economic push factors for aspiring migrants. For instance, better jobs and pay was the most straightforward motivation option in the questionnaire and might have been overrepresented. Moreover, there is often a dissonance between the reasons an individual offers for an action and the true factors driving that action. As an analogy, voters may convey that they support a political candidate for economic reasons, but there may be other unmentioned factors that may be significantly affecting their vote choice, such as ethnic or religious identity or political party affiliation. Similarly, migrants might say that they left home in hopes of finding a good job, even though other factors are motivating their desire to leave their country. There are many factors that could have an effect on the desire to migrate. This paper specifically aims to shed light on the factors pushing Nigerians to leave their home country.

\section{The desire to migrate in Nigeria}

In order to overcome this lacuna in the research, a number of variables are tested that may potentially have an effect on individual desire to migrate. This case study relies on survey data from Nigeria to examine the effect of a variety of push factors on the desire of Nigerians to migrate. It endeavours to ascertain whether socio-economic status has a significant effect on migration or if there are other factors, thus far not identified, that may have a more significant effect on the phenomenon. The dependent variable is Nigerians' desire to migrate if given the opportunity. The question is worded as follows: "If you had the means and opportunity, would you prefer to live or work in another country or would you prefer to stay in Nigeria?"

Nigeria was selected as a case study for several reasons. First, it is striking that, in the survey data, $50 \%$ of Nigerians would leave their country if they had the means and the opportunity to do so. Second, Nigeria's population represents nearly half of the region. 
Nigerians quite simply comprise the vast majority of the people who are motivated to migrate in West Africa. There is also interesting in-country variation in the desire to migrate (Map 1). Finally, Nigeria is also the country of origin for more than a quarter of all migrants traveling through the Central Mediterranean route (IOM, 2017).

$\underline{\text { Map } 1}$

Desire to migrate by region in Nigeria

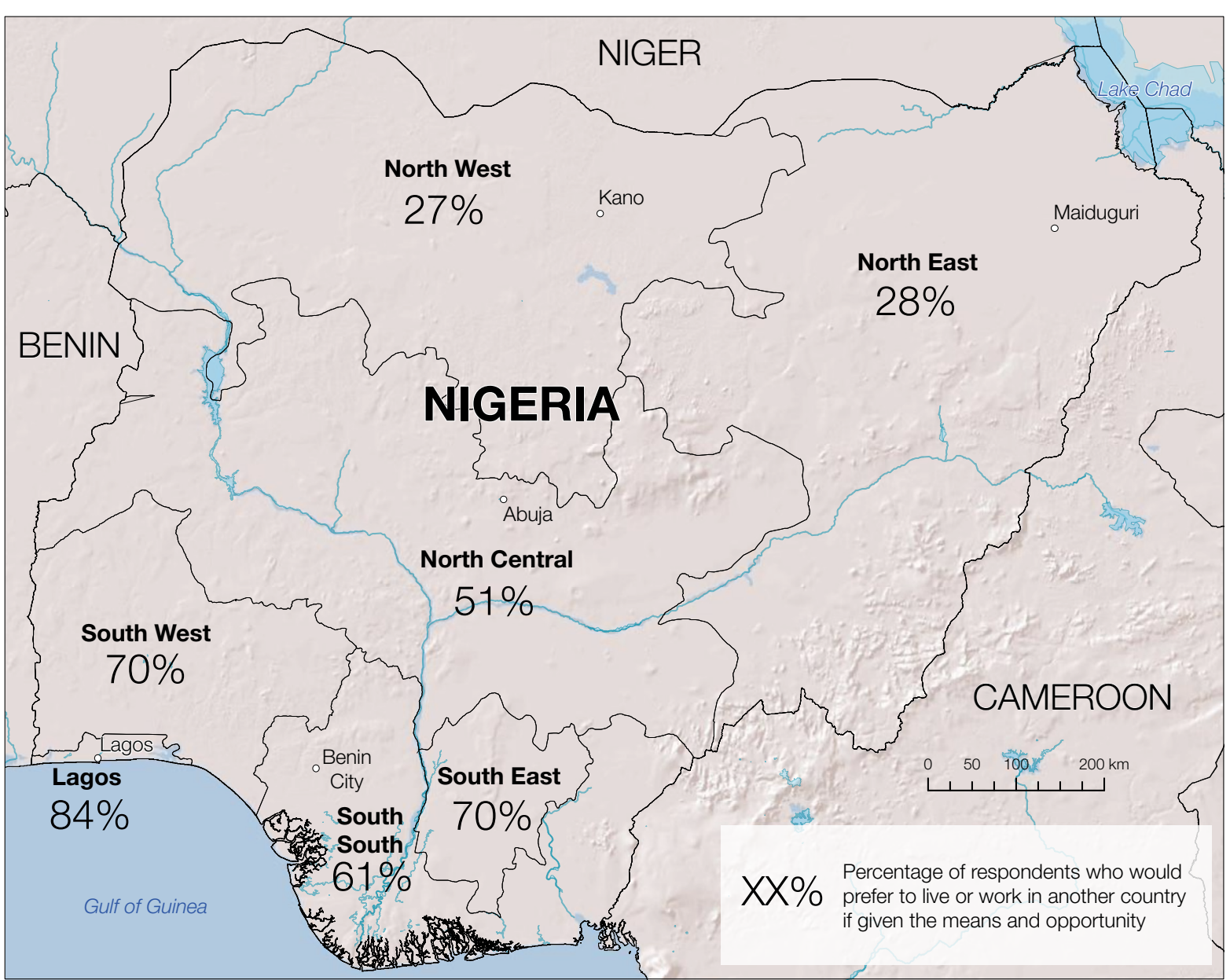

Source: Nationwide survey, December 2016. Cartography: Olivier Walther, 2018.

Examining a Nigerians' desire to leave their country if given the opportunity is useful for several reasons. First, it examines potential migrants instead of actual migrants. By doing so, it can better capture the motivations of all Nigerians that might want to migrate abroad. Examining actual migrant flows will under-represent, for instance, the number of women or people from rural areas that are motivated to migrate abroad. These populations are often less likely to migrate because of financial barriers to entry, risk tolerance, social norms, and other constraining conditions (Black and Collyer, 2014; Carling, 2002; Kothari, 2002). By examining Nigerians who are motivated to migrate abroad, regardless of whether or not they are able to do so, the potential for a selection effect, in which migrants view or express their motivations differently than aspiring migrants, is eliminated.

\section{Statistical model}

A logit model is applied to see if there is a relationship between key independent variables and the dependent variable of Nigerians' desire to leave their country if given the opportunity. Relying on the survey data, the desire to leave is represented as a binary dependent variable. Several models were tested and the most efficient model identified was one that sacrifices some explanatory power for greater simplicity. The dependent and independent variables are summarised below. 
Table 2

Summary of variables in logit models

\section{Description and measurement}

$\begin{array}{ll}\begin{array}{l}\text { Dependent variable } \\ \begin{array}{l}\text { Desire to leave if given } \\ \text { means/opportunity }\end{array}\end{array} & \begin{array}{l}\text { If you had the means and opportunity would you prefer to live or work in another country or } \\ \text { would you prefer to stay in [COUNTRY]? }\end{array} \\ \begin{array}{l}\text { Independent variables } \\ \text { 1-year economic decline }\end{array} & \begin{array}{l}\text { Compared with a year ago, would you say that your household's economic situation has } \\ \text { improved, stayed the same, or worsened? }\end{array} \\ \text { Relative economic prosperity } & \begin{array}{l}\text { Compared with other families in this community, do you think that your family's standard of } \\ \text { living is much higher, a little higher, about average, a little lower or much lower? }\end{array} \\ \text { Employment } & \begin{array}{l}\text { Which of the following best describes your present employment status? Working full time in a } \\ \text { paid job, self-employed, part-time, retired, unemployed, unable to work, student, housewife, } \\ \text { apprentice? }\end{array}\end{array}$

Public education

How would you rate the quality of education in your community: very good, good, fair, or poor?

Water service delivery

How would you rate the quality of water in your community: very good, good, fair, or poor?

Quality of democracy

How satisfied or dissatisfied are you with the way democracy works in [COUNTRY] today very satisfied, somewhat satisfied, not very satisfied or not at all satisfied?

Ethnic discrimination

In your experience, does the government of [COUNTRY] treat people from your ethnic group better, the same, or worse than people from other ethnic groups

Safety

How safe do you feel here in [CITY/TOWN/VILLAGE]? Do you feel very safe, fairly safe, not very safe, or not safe at all?

Fighting terrorism

How well would you say the government is doing fighting terrorism?

Trust in police

I would like you to tell me how much trust you have in the following people and groups...Do you have a lot of trust, a fair amount of trust, only a little trust, or no trust at all in the police?

Corruption

How much do you agree or disagree with the following statement? Corruption is part of life in [COUNTRY] and there is nothing we can do to change it. Do you strongly agree, agree, disagree or strongly disagree?

Religion

What religion, if any, do you practice? (0ther=0, Muslim=1)

Internet use

How often do you use the internet, if at all? Never, several times a year, several times a week, several times a week, or everyday?

Gender

Observed; Male $=1$, Female $=0$

Age

What is your age? [Exact number]

Education level

What is the highest level of schooling you have reached? Informal schooling, some primary schooling, primary schooling complete, some secondary/high school, secondary/high school complete, post-secondary qualifications, some university, or university complete?

Urbanity

Based on sample; Rural $=1$, Urban $=0$

Lagos

Based on sample; Lagos $=1$, Else $=0$

Note: All data is sourced from a nationwide opinion survey conducted in Nigeria in December 2016. 
Different sets of variables are specified. The first set looks at non-economic motivations for migration that draw from the survival migration literature as well as the Nigerian context (i.e. predatory local security, corruption, quality of public education, discrimination against ethnic groups, and the government's ability to fight terrorism). The survival migration literature suggests that people will migrate when the state cannot provide basic public goods, so basic service delivery through Nigerians' access to water is also examined.

Different sets of control variables are also specified. First, three key economic factors are examined that might affect a Nigerian's desire to leave their country: declining economic status, relative economic status, and employment. Finally, we control for a set of demographic variables on gender, religion, urban status, age and education level.

\section{Insecurity not a driver in desire to migrate}

There is sub-national variation in Nigerians' desire to migrate that is worth noting. For instance, North East Nigeria has been, by far, the region the most deeply affected by Boko Haram violence, yet desire to migrate is comparatively low and on par with levels in North West Nigeria, a region that does not face high levels of insecurity. This suggests that insecurity is not necessarily a key driver in desire to migrate. Another explanation could be that individuals in North East Nigeria are in such a marginalised state that migration does not seem to be a viable option for them.

Meanwhile, a striking proportion of Nigerians who wish to leave are from Lagos. This may be due to several factors. First, there is mixed evidence that those with moderate means (i.e. neither the most affluent, nor the poorest) are most likely to migrate abroad, and this socio-economic class is most prominent in urban areas. Second, Lagos might reflect the social network effect that occurs in a city, in which Nigerians share their interests in migrating abroad. Finally, it might also capture the cultural identity of Lagos as a 'city of strivers', in which people are most likely to imagine taking a migration journey. Lagos is often the destination for rural Nigerians who wish to transition from a life based on agrarian subsistence to a cash-based existence. The massive expansion of Lagos from a city of 2690000 (three million) in 1980 to today's city of 13701000 (14 million) according to Africapolis data (OECD/SWAC, forthcoming), reflects this rural to urban migration. This trend is likely to continue as Nigeria's population is expected to double by 2050, with half the population residing in cities and six-in-ten under the age of 25 (BBC, 2017).

South-west Nigeria also has high numbers of individuals wishing to migrate (70\%). Clandestine migration originating in Edo State (located in South West Nigeria) has been well documented (Taub, 2017). As a symptom of the phenomenon, the IOM went so far as to establish a migrant resource centre (MRC) in Benin City in Edo State in March 2018 (IOM, 2018). Up until that moment, the only MRCs in Nigeria were found in Lagos and Abuja.

\section{Economic development does not discourage migration}

This study finds that a Nigerian's domestic economic status does not have a significant effect on desire to migrate (Table 3). Economic factors, such as relative economic status and employment, all had an insignificant and very low relationship with the desire to migrate, while declining economic status is significant but only at the .05 level. Moreover, the R-squared does not increase from the political/security model to the economic factor model, which means that economic factors offer little explanatory value in variation in the dependent variable. This suggests that the desire to leave Nigeria cuts across multiple economic levels and it supports the finding that economic development does not discourage migration until it reaches a high per capita income level. 
$\underline{\text { Table } 3}$

Factors affecting the desire to migrate from Nigeria

\begin{tabular}{|c|c|c|c|}
\hline & $\begin{array}{l}\text { Political \& security } \\
\text { factors (1) }\end{array}$ & $\begin{array}{c}\text { Economic factors } \\
\text { (2) }\end{array}$ & $\begin{array}{c}\text { Demographic } \\
\text { characteristics (3) }\end{array}$ \\
\hline Satisfied with democracy & $-.361^{\star \star \star}$ & $-.352^{\star \star \star}$ & $-.264^{\star \star \star}$ \\
\hline Trust in police & $-.359^{\star \star \star}$ & $-.358^{\star \star \star}$ & $-.236^{\star * \star}$ \\
\hline Corruption & .048 & $.062^{*}$ & $.122^{\star \star}$ \\
\hline Ethnic discrimination & -.017 & -.020 & .044 \\
\hline Service delivery (education) & .011 & $.019^{\star \star \star}$ & -.040 \\
\hline Service delivery (water) & $-.183^{\star \star \star}$ & $-.184^{\star \star \star}$ & $-.139^{\star \star}$ \\
\hline Govt. fighting terrorism & $-.144^{\star \star}$ & $-.149^{\star \star \star}$ & -.043 \\
\hline Employment & & -.049 & -.007 \\
\hline Relative economic status & & .026 & -.056 \\
\hline 1-year economic decline & & $.096^{\star}$ & $.154^{\star \star}$ \\
\hline Gender & & & .239 \\
\hline Religion (Muslim) & & & $-.716^{\star \star \star}$ \\
\hline Education level & & & $.087^{\star \star \star}$ \\
\hline Urban/rural & & & $.224^{* *}$ \\
\hline Lagos & & & $1.431^{\star \star \star}$ \\
\hline Age & & & $-.047^{\star \star \star}$ \\
\hline R-squared & .09 & .09 & .17 \\
\hline Observations & 3598 & 3525 & 3523 \\
\hline
\end{tabular}

Note: ${ }^{*}<.10,{ }^{* *}<.05,{ }^{* *}<.01$. Log odds units are reported.

Source: Nationwide survey, December 2016.

Meanwhile, apart from the demographic variables, the strongest relationships in the model are factors related to good governance: satisfaction with democracy and trust in the police. Nigerians who are unhappy with the state of democracy are more likely to wish to leave their country. How Nigerians' regard their government and the quality of democracy have been sorely neglected in West African migration literature to date and this finding could potentially spur greater conversation on Nigerians' satisfaction with how they are governed.

Following satisfaction with democracy, Nigerians' desire to migrate abroad had the strongest relationship with trust in the police. The reputation of Nigerian security forces has been well documented in journalistic and academic reporting. Multiple reports have accused the police in Nigeria of human rights abuse, coercion and bribery, and, according to polling, the police have typically been one of the least trusted institutions in Nigeria (Bratton and Gyimah-Boadi, 2016).

Surprisingly, discrimination against ethnic groups had an insignificant relationship with the desire to migrate. Nigeria has experienced ethnic tensions throughout its history as evidenced by farmer-herder conflict that frequently exhibits ethnic dimensions and a Civil War based on Igbo secession. Nigerians may desire to stay home and not risk further discrimination on the basis of their ethnicity in a foreign country.

The study also examined the government's ability to fight terrorism. In the first two models, it had a strong and significant effect on individual desire to migrate but it was no longer significant in the third model that controlled for demographic factors. 
Government provision of public education also had a weak and insignificant effect on the desire to migrate. On the one hand, this is surprising since access to education is a commonly cited motivation for migration. On the other hand, this finding makes sense in light of how focus group participants often mentioned that their education was little help for their life circumstances.

Meanwhile, Nigerians' access to water as part of service delivery had a significant effect on the desire to migrate. This finding fits in with the survival migration literature that suggests people will seek to migrate when the state cannot provide basic public goods.

\section{Educated urban Nigerians more interested in migrating}

The demographic profile of those who wish to leave is non-Muslim, educated, urban residents who use the Internet frequently. The fact that educated urban residents who use the internet frequently have a strong interest in migrating reveals that it is not necessarily the worst-off who dream of migrating abroad. Indeed, Nigerians who use the Internet frequently and who have a favourable opinion of the United States are also more likely to want to migrate. These two factors which suggest a higher level of connectedness and openness to the outside world, encourage the desire to migrate. Individuals still residing on the African continent are able to see, via social media, an idealised picture of immigrant life in Europe that does not fully comport with their daily struggles. This may in turn drive migration and there is anecdotal evidence to support this assertion (The Guardian, 2016).

Nigerians with higher levels of education are also more likely to want to migrate. This confirms the accounts of many of the focus group participants who recounted that they had earned academic degrees but were unable to find employment and had thus decided to migrate. This finding lends credence to the previously cited IMF report (2016) that Africa is increasingly susceptible to social capital flight.

Other factors are surprising for their insignificant effects. For instance, gender has an insignificant effect on willingness to migrate. This finding makes sense in light of how, $30 \%$ of Nigerians arriving in Italy in 2017 were women. This is much higher than other African nationalities, suggesting that cultural and social taboos do not prevent Nigerian women from migrating as they might in other West African countries. As a point of comparison, Guineans were the next most significant African nationality arriving on the shores of Italy and only 4\% were females. The case of Senegal is even starker; $1 \%$ of the 6000 Senegalese that arrived to Italy by sea were female.

As expected Lagosians are significantly more likely to desire to migrate than Nigerians in other parts of the country. There is something unique about Lagos because this variable is also much more significant than urbanity. Lagosians have a much greater appetite for migration than individuals in other urban areas. Perhaps the cosmopolitan nature of Lagos makes individuals there even more open to the prospects of moving to a foreign country.

There is a gap between Nigerians that wish to leave and those who are able to do so, as well as a gap between those who might be expected to wish to leave and those who actually want to do so. Those most exposed to violence, such as Boko Haram, are less likely to want to leave, even though there are good reasons to believe they would want to flee their homes. Meanwhile, 50\% of Nigerians are motivated to leave their home country, even though far less people actually end up migrating. This is revealing about the desire to migrate; it appears to hinge on exposure to opportunity and the ability to imagine a life in another country. 


\section{CONCLUSIONS}

This paper draws attention to the motivations of West Africans that wish to migrate, offering a more complete picture of the push factors behind the Central Mediterranean migration route. By examining Nigerians who are motivated to migrate abroad, regardless of whether or not they are able to do so, the study mitigates the possibility for a selection effect in how migrants view their circumstances and goals vis-a-vis aspiring migrants. In doing so, it was found that Nigerians are most likely pushed to migrate due to daily concerns about the democratic performance of their state as well as the extent to which they can trust one element of the state security apparatus, the police.

For donor governments interested in curbing migration from West Africa to Europe, this paper provides new evidence on domestic policy steps that could address the grievances and concerns of those who seek to migrate. Promoting good governance rather than economic development could be more effective in providing West Africans with the hope that they can live a fulfilling life in their country of origin.

The quantitative model in this paper focuses on Nigeria, but future research could be expanded to include other West African countries. One potential avenue of research could be to examine a country where few are looking to migrate, such as Burkina Faso and Niger, and identify the factors responsible for these individual attitudes. Additional research with aspiring migrants can shed further light on why people want to leave their country. Only a small minority of those who wish to migrate actually do so. As access to disposable income and other resources increases in the country of origin, more West Africans will be able to migrate. Understanding motivations to migrate among aspiring migrants will be essential for understanding and addressing future migration patterns. 


\section{REFERENCES}

Betts, A. (2013), "State fragility, refugee status and 'survival migration'”, Forced Migration Review No. 43, pp. 4-6.

Black, R. and M. Collyer (2014), "Populations 'trapped' at times of crisis", Forced Migration Review No. 45, pp. 52-56.

Brachet, J. (2018), "Manufacturing Smugglers: From Irregular to Clandestine Mobility in the Sahara", The Annals of the American Academy of Political and Social Science, Vol. 676/1, pp. 16-35.

Bratton, M. and E. Gyimah-Boadi (2016), "Do trustworthy institutions matter for development? Corruption, trust, and government performance in Africa", Afrobarometer Dispatches 112.

BBC (2017), "The City that Won’t Stop Growing”, 21 August, https://www.bbc.co.uk/news/resources/idt-sh/ lagos.

Carling, J. (2002), "Migration in the age of involuntary immobility: Theoretical reflections and Cape Verdean experiences", Journal of Ethnic and Migration Studies, Vol. 28/1, pp. 5-42.

Charrière, F. and M. Frésia (2008), West Africa as a Migration and Protection Area, UN High Commissioner for Refugees (UNHCR), www.refworld.org/docid/4a277db82.html, accessed 23 May 2018.

Clemens, M. (2014), “Does Development Reduce Migration?", Center for Global Development Working Paper No. 359.

De Haas, H. (2010), "Migration transitions: A theoretical and empirical inquiry into the developmental drivers of international migration", University of Oxford, International Migration Institute Working Paper 24.

Grégoire, E. (1999), Touaregs du Niger, le destin d'un mythe, Karthala, Paris.

Hatton, T. and J. Williamson (1994), Migration and the International Labor Market, 1850-1939, Taylor \& Francis.

IMF (2016), World Economic Outlook, October, International Monetary Fund, Washington, DC.

IOM (2018), Nigeria UN Migration Agency Launches Migrant Resource Center in Benin City, Nigeria, Le GrandSaconnex, International Organization for Migration, https://nigeria.iom.int/media/news/un-migrationagency-launches-migrant-resource-center-benin-city-nigeria, accessed 23 May 2018.

IOM (2017), Mixed Migration Flows in the Mediterranean: Compilation of Available Data and Information, December, Le Grand-Saconnex, International Organization for Migration, https://reliefweb.int/report/ world/mixed-migration-flows-mediterranean-compilation-available-data-and-information-december, accessed 23 May 2018.

IRIN (2015), "Taking the back Way Out: The Gambia to Italy", 8 October.

Kothari, U. (2002), "Migration and Chronic Poverty", Institute for Development Policy and Management, University of Manchester, Working Paper No. 16.

Lucas, R.E. (2005), International Migration and Economic Development: Lesson from Low Income Countries, Edward Elgar Publishing, Cheltenham.

McCormick, T. (2017), "The Paradox of Prosperity, Foreign Policy", October 4, http://europeslamsitsgates. foreignpolicy.com/part-1-the-paradox-of-prosperity-mali-africa-europe-EU-migration.

OECD/SWAC (forthcoming), "Africapolis: Urbanisation Dynamics in Africa", West African Studies, OECD Publishing, Paris. 
Pew Research Center (2018), "International Migration from sub-Saharan Africa has grown dramatically since 2010", February, www.pewresearch.org/fact-tank/2018/02/28/international-migration-from-sub-saharanafrica-has-grown-dramatically-since-2010/, accessed 23 May 2018.

Raineri, L. (2018), "Human smuggling across Niger: state-sponsored protection rackets and contradictory security imperatives", The Journal of Modern African Studies, Vol. 56/1, pp. 63-86.

Sassen, S. (1990), The Mobility of Labor and Capital: A Study in International Investment and Labor Flow, Cambridge University Press, Cambridge.

Stark, O. (2006), "Inequality and migration: A behavioral link", Economics Letters No. 91, pp. 146-152.

Taub, B. (2017), "The Desperate Journey of a Trafficked Girl”, The New Yorker, April.

The Guardian (2016), "Gambian migrants who risk death find life less than sweet in Italy”, May 6.

UNHCR (2017), "Figures at a glance”, www.unhcr.org/en-us/figures-at-a-glance.html, accessed 23 May 2018.

Walther, O. (2017), "Wars and Conflicts in the Sahara-Sahel", OECD West African Papers, No. 10, http://dx.doi. org/10.1787/8bbc5813-en.

World Bank (2018), Groundswell: Preparing for Internal Climate Migration, The World Bank, Washington, DC. 


\section{ALSO IN THE WEST AFRICAN PAPERS SERIES:}

Allen, T. and P. Heinrigs (2016), "Emerging Opportunities in the West African Food Economy”, http://dx.doi.org/10.1787/5jlvfj4968jb-en

Lewis, K. and C. Buontempo (2016), "Climate Impacts in the Sahel and West Africa: The Role of Climate Science in Policy Making", http://dx.doi.org/10.1787/5jlsmktwjcd0-en

Gnisci, D. (2016), “Women's Roles in the West African Food System: Implications and Prospects for Food Security and Resilience", http://dx.doi.org/10.1787/5jlpl4mh1hxn-en

Staatz, J. and F. Hollinger (2016), "West African Food Systems and Changing Consumer Demands",

http://dx.doi.org/10.1787/b165522b-en

Prieto Curiel, R., P. Heinrigs and I. Heo (2017), “Cities and Spatial Interactions in West Africa: A Clustering Analysis of the Local Interactions of Urban Agglomerations",

http://dx.doi.org/10.1787/57b30601-en

Walther, O. (2017), "Cross-border Co-operation Networks in West Africa", http://dx.doi.org/10.1787/73298292-en

Ibrahim, I.Y. (2017), “The Wave of Jihadist Insurgency in West Africa: Global Ideology, Local Context, Individual Motivations",

http://dx.doi.org/10.1787/eb95c0a9-en

Allen, T. (2017), "The cost of high food prices in West Africa",

http://dx.doi.org/10.1787/c2db143f-en

Van Den Hoek, J. (2017), “Agricultural market activity and Boko Haram attacks in northeastern Nigeria",

http://dx.doi.org/10.1787/13ba9f2e-en

Walther, O. (2017), "Wars and Conflicts in the Sahara-Sahel", http://dx.doi.org/10.1787/8bbc5813-en

Elisher, S. (2018), “Defying the Odds? Nigerien Responses to Foreign and Domestic Security Challenges",

https://doi.org/10.1787/104d1c6d-en

Eizenga, D. (2018), "The Unstable Foundations of Political Stability in Chad", https://doi.org/10.1787/508844d3-en

Bouchama, N. et al. (2018), “Gender Inequality in West African Social Institutions", http://dx.doi.org/10.1787/fe5ea0ca-en

Allen, T., P. Heinrigs and I. Heo (2018), “Agriculture, food and jobs in West Africa", https://doi.org/10.1787/dc152bc0-en

van Wesenbeeck, C.F.A. (2018), “Disentangling Urban and Rural Food Security in West Africa", https://doi.org/10.1787/e0c75266-en

Hoffmann, L.K. and P. Melly (2018), "Incentives and constraints of informal trade between Nigeria and its neighbours",

https://doi.org/10.1787/7aa64379-en

For more information on the series, please contact:

lia.beyeler@oecd.org

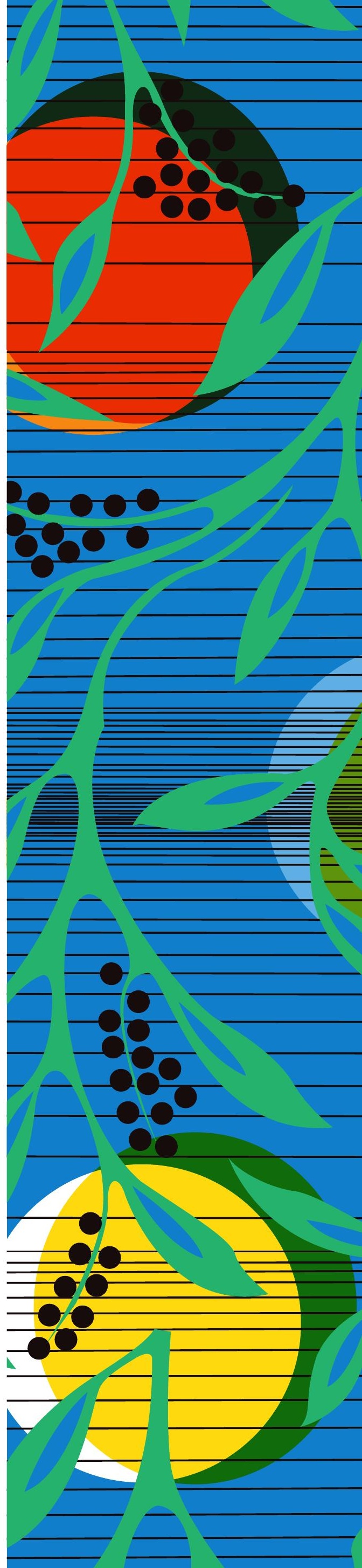

